\title{
Effect of Fermentation of Acacia Leaves (Acacia Mangium) Using Aspergillus Niger on Nutrient Content
}

\author{
Sri Sukaryani ${ }^{1}$, Engkus Ainul Yakin ${ }^{2}$, and Diyah Kartika Wulan ${ }^{3}$ \\ ${ }^{1,2,3}$ Program Study of Animal Husbandry, Faculty of Agriculture, \\ Universitas Veteran Bangun Nusantara Sukoharjo \\ Corresponding author : engkus_ainul@yahoo.com
}

\begin{abstract}
Acacia (Acacia mangium) was a multipurpose plant, useful for fuel, hedge plants, and available throughout the year. Fermentation on acacia leaves needs to be done to reduce crude fiber and increase the dissolved protein content of the feed ingredients. This study aims to determine the effect of the nutritional content of acacia leaves (Acacia magium) fermented using Aspergillus niger as much as 0-2\%. The method used in this research were the experimental method of fermenting acacia leaves (Acacia magium). The experimental design used was a completely randomized design (CRD) consisting of three treatments and three repetitions. The treatments were as follows: $\mathrm{P} 0=$ Fermentation with Aspergillus niger as much as $0 \%$ of 300 grams of acacia leaves, $\mathrm{P} 1=$ Fermentation with Aspergillus niger as much as $1 \%$ of 300 grams of acacia leaves, $\mathrm{P} 2=$ Fermentation with Aspergillus niger as much as $2 \%$ of 300 grams of acacia leaves for 7 days. Parameters observed were soluble protein, crude fat, crude fiber. The average value of crude fat P0: 7.18\%, P1: 8.33\%, P2:15,47\%. The average value of dissolved protein content P0: $2.89 \%, \mathrm{P} 1: 2.93 \%, \mathrm{P} 2: 3,51 \%$. The average value of crude fiber P0: $68.23 \%$, P1: $68.40 \%, \mathrm{P} 2: 68.90 \%$. From the results of this study, it can be concluded that Acacia leaves (Acacia Mangium) fermented using Aspergillus niger had a significant effect on crude fat content, but did not significantly affect soluble protein content and crude fiber content of acacia (Acacia Mangium) leaves.
\end{abstract}

Keywords: Aspergillus niger, acacia leaf, fermentation, nutritional content

\section{Introduction}

Indonesia is an archipelagic country, it is proven that in Indonesia there are various plants that have many benefits. One example of a plant found in Indonesia is the Acacia plant (Acacia mangium). Acacia is a multipurpose plant, useful as a fuel, hedge plant, and available all year round.

Acacia has a taproot. Acacia stems are long, round and the top of them is used for paper making. Acacia leaves are green and have a long and oval leaf shape. Acacia has yellow flowers and has two fruit seeds. Acacia leaf production is harvested 3 times until 16 months after planting. Crude protein content in acacia leaves is $14.00 \%$, crude fat is $2.76 \%$, crude fiber is $30.58 \%$, TDN $62.97 \%$ but acacia leaf intake tends to be low compared to other plants.

Feed is the intake given to livestock which is a source of energy and minerals for livestock growth. The most important substances in feed are protein and fiber. 
Nutritionally, these feed ingredients have high crude fiber content, so it is necessary to manipulate nutrients to reduce crude fiber and increase the value of soluble protein in the feed ingredients. Fermentation on acacia leaves needs to be done to reduce crude fiber and increase the dissolved protein content of the feed ingredients.

The purpose of this study was to determine the effect of the nutritional content of acacia leaves (Acacia magium) fermented using Aspergillus niger.

\section{Materials and methods}

This research will be carried out for 2 to 3 months in the laboratory of the Faculty of Agriculture, Universitas Veteran Bangun Nusantara Sukoharjo.

\section{Research Material}

This research is an experimental study using research material, namely acacia leaves (Acacia Mangium). The materials used are acacia leaves (Acacia mangium) from the village of Pondok, Aspergillus niger, molasses and petro urea.

The tools used in the study were ohaus electric scales, oven, fermentation rack, scales, basins, transparent plastic bags, aluminum foil, filter paper, test tubes, lighters, $50 \mathrm{ml}$ Erlenmeyer and tools used in proximate analysis, namely Analytical Balance, 250 $\mathrm{ml}$ khejdal tube, destructor, measuring flask, funnel, $5 \mathrm{ml}$ scale pipette, suction pump, $100 \mathrm{ml}$ measuring cup, $50 \mathrm{ml}$ measuring cup, distillation flask, distillator, $50 \mathrm{ml}$ erlemeyer, electric bath, $100 \mathrm{ml}$ test tube, oven and incubator.

\section{Experimental design}

The study was conducted using a completely randomized design (CRD) with a unidirectional pattern consisting of 4 treatments with 3 replications. Fermentation was carried out for 1 week. The treatment is as follows:

$\mathrm{P} 0=$ Fermentation with Aspergillus niger as much as $0 \%$ of 300 grams of acacia leaves. P1 $=$ Fermentation with Aspergillus niger as much as $1 \%$ of 300 grams of acacia leaves. P2 $=$ Fermentation with Aspergillus niger as much as $2 \%$ of 300 grams of acacia leaves.

\section{Observed Parameters}

The parameters observed in this study were the content of Dissolved Protein and Crude Fiber, each of which was measured by:

1. Soluble protein is calculated by:

Soluble protein $=\frac{(y-a) b x f p}{\text { sample weight }} \times 100 \%$

$\mathrm{y}=$ absorbance of sample solution

$\mathrm{a}, \mathrm{b}=$ from BSA . standard curve regression equation

$\mathrm{fp}=$ dilution factor

2. Crude fat is calculated by:

Fat $=$ weight of ingredients- weight of residual fat $\times 100 \%$

3. Crude fiber is calculated by:

$$
\text { Sample weight }
$$

Crude fiber $=\frac{\mathrm{a}-\mathrm{b}}{\mathrm{c}} \times 100 \%$ 


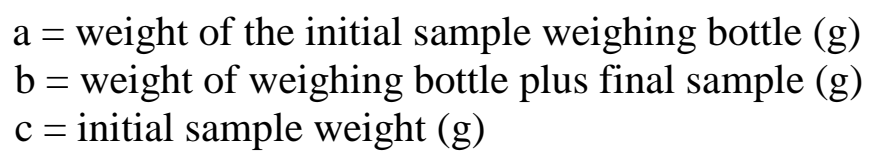

\section{Data Analysis}

The data obtained were processed statistically using analysis of variance (ANOVA) based on a completely randomized design (CRD) with a unidirectional pattern. If the results of the variance test are different or have an effect, then further tests are carried out using Duncan's multiple region test (Mulyono, 2011).

\section{Research procedure}

Making acacia leaf fermentation by weighing 300 grams of acacia leaves, preparing a starter that has been ripened for 1 week, preparing $30 \mathrm{cc}$ of molasses, 1.5 grams of urea, and aquades. Then put the acacia leaves into the bucket then add the starter which has been dissolved with aquades as much as the treatment. After that, stir until smooth, then add 1.5 grams of urea that has been dissolved in distilled water, stir again until smooth, then add $30 \mathrm{cc}$ of molasses that has been dissolved in distilled water, mix until smooth, add the remaining aquadest and stir again until smooth, cover with a thin cloth already in small holes, then let stand for 7 days, after 7 days it is opened and then aired

1. Dissolved Protein Level

The procedure for measuring dissolved protein levels using the Lowry method is as follows:

a. Before measuring the dissolved protein first make reagents a, b, c, d and e:

1) Preparation of Reagent $A$ as follows:

2 grams of $\mathrm{NaOH}$ and 10 grams of $\mathrm{Na}_{2} \mathrm{CO}_{3}$ were dissolved using $100 \mathrm{ml}$ of distilled water.

2) Preparation of Reagent B as follows:

1 gram of $\mathrm{CuO} 4$ is dissolved in $100 \mathrm{ml}$ of distilled water

3) Preparation of Reagent $C$ as follows:

2 grams of K-Na-Tatrate dissolved in $100 \mathrm{ml}$ of distilled water.

4) Preparation of Reagent $D$ as follows:

Mix $15 \mathrm{ml}$ of reagent A, $0.75 \mathrm{ml}$ of reagent $\mathrm{B}$ and $0.75 \mathrm{ml}$ of reagent then shake until homogeneous.

5) Preparation of Reagent $\mathrm{E}$ as follows:

$10 \mathrm{ml}$ of Folin-Ciocalteu was dissolved in $90 \mathrm{ml}$ of distilled water.

b. Dissolved Protein Measurement

1) Samples from various treatments were weighed as much as 1 gram

2) The sample that has been weighed is put in an erlenmeyer, dissolved using $100 \mathrm{ml}$ of distilled water and put into a measuring flask,

3) Take $1 \mathrm{ml}$ of the solution and put it in a test tube

4) Add reagent $\mathrm{D} 1 \mathrm{ml}$ vortex until dissolved and let stand for 15 minutes.

5) After 15 minutes, add $3 \mathrm{ml}$ of reagent $\mathrm{E}$, then vortex again and let stand for 45 minutes.

6) After 45 minutes, measure using a spectro with a wavelength of $540 \mathrm{~nm}$ 
2. Crude fat content
a. Samples from various treatments were weighed as much as 1 gram
b. Then wrap it using filter paper and tie it with thread
c. Then enter it into the soxlet, wait for 7 rounds until the solvent drops back to gray on a clear round bottom.
d. Then put the sample that has come out of the soxlet into the oven for 1 hour at a temperature of $105 \mathrm{oC}$
e. If it's been 1 hour, remove it from the oven and put it in a desiccator for 15 minutes
f. After 15 minutes in the desiccator, the sample was weighed again.
g. Fat weight can be calculated

3. Crude Fiber Content
a. Samples from various treatments were weighed as much as 0.5 grams
b. The sample that has been weighed is put in an erlenmeyer, dissolved using $30 \mathrm{ml}$ of $\mathrm{H} 2 \mathrm{SO} 4$ and put into a water bath for 30 minutes.
c. After 30 minutes, remove the sample and mix it with $15 \mathrm{ml}$ of $\mathrm{NaOH}$ and put it in the water bath for 30 minute.
d. After 30 minutes, remove the sample and then wash / filter using $50 \mathrm{ml}$ of water, $50 \mathrm{ml}$ of $\mathrm{H} 2 \mathrm{SO} 4,50 \mathrm{ml}$ of hot water, $50 \mathrm{ml}$ of alcohol.
e. Then bake in the oven for 8 hours
f. After being in the oven, weigh the samples

\section{Results and Discussion}

\section{Dissolved Protein}

The results of the research on soluble protein content of acacia leaf fermentation using Aspergillus niger are listed in Table 1.

Table 1. Average Dissolved Protein Content of Acacia Leaves Fermented With Aspergillis Niger (\%)

\begin{tabular}{cccc}
\hline \multirow{2}{*}{ Repeat } & \multicolumn{3}{c}{ Treatment } \\
\cline { 2 - 4 } & $\mathrm{P} 0$ & $\mathrm{P} 1$ & $\mathrm{P} 2$ \\
\hline 1 & 3.24 & 3.07 & 4.53 \\
2 & 3.40 & 2.14 & 3.66 \\
3 & 2.08 & 2.58 & 3.96 \\
4 & 2.83 & 2.63 & 2.65 \\
5 & 2.60 & 3.25 & 3.19 \\
6 & 3.22 & 3.91 & 3.07 \\
\hline Average $^{\mathrm{ns}}$ & 2.89 & 2.93 & 3.51 \\
\hline
\end{tabular}

Description ns : Non significant ( $\mathrm{P}>0.05$ )

Based on table 1, the soluble protein in acacia leaf fermentation using Aspergillus niger showed the average values for P0, P1, and P2 treatments, namely $2.89 \%, 2.93 \%$, and $3.51 \%$. 
The results of statistical analysis showed that acacia leaves fermented using Aspergillus niger as much as $0-2 \%$ had no significant effect $(\mathrm{P}>0.05)$ on soluble protein. The addition of Aspergillus niger into the fermented acacia leaves did not affect the soluble protein content of the acacia leaves. If seen visually, the soluble protein content of fermented acacia leaves using Aspergillus niger has increased. This is in line with the opinion of Indrayanti (2013) that the higher the level of Aspergillus niger, the higher the protein content. This is because the source of single cell protein is obtained from the contribution of nitrogen by the nucleic acids contained in Aspergillus niger. Reed and Nagodhawithna (1988) in the research of Nuryana et. al., (2016) stated that an increase in substrate protein will occur by two things, namely an increase in yeast biomass (MBP) and an increase in yeast sec which functions as a single cell protein agent (PST). According to Supriyatna (2017) this increase in protein is caused by protein synthesis by the mold consortium. In addition, the increase in protein was also due to an increase in the mycelium of molds on the substrate. The increase in protein content can also be caused by the start of fungal growth restriction by energy or nitrogen in the substrate so that fiber digestion is reduced.

\section{Crude Fat}

The results of the study on crude fat content of acacia leaf fermentation using Aspergillus niger are listed in Table 2.

Table 2. Average Crude Fat Content of Acacia Leaves Fermented with Aspergillis Niger (\%)

\begin{tabular}{cccc}
\hline \hline \multirow{2}{*}{ Repeat } & \multicolumn{3}{c}{ Treatment } \\
\cline { 2 - 4 } & P0 & P1 & P2 \\
\hline 1 & 6.70 & 6.70 & 14.90 \\
2 & 6.20 & 6.20 & 14.80 \\
3 & 7.60 & 7.60 & 15.20 \\
4 & 8.10 & 8.10 & 14.70 \\
5 & 7.20 & 7.20 & 16.60 \\
6 & 7.30 & 7.30 & 16.60 \\
\hline Average & $7.18^{\mathrm{a}}$ & $8.33^{\mathrm{b}}$ & $15.47^{\mathrm{c}}$
\end{tabular}

Description $^{\mathrm{a}, \mathrm{b}, \mathrm{c}}$ : Different superscripts on the same line show significant differences $(\mathrm{P}<0.05)$

Based on table 2, crude fat content in acacia leaf fermentation using Aspergillus niger had a significant effect $(\mathrm{P}<0.05)$ on crude fat content. These differences were found in treatments $\mathrm{P} 0$ and P1 with crude fat content values of $7.18 \%$ and $8.33 \%$, treatments $\mathrm{P} 0$ and $\mathrm{P} 2$ had a significant effect on crude fat content values of $7.18 \%$ and $15.47 \%$, respectively. This significant effect also occurred in treatments P1 and P2 with crude fat values of $8.33 \%$ and $15.47 \%$, respectively.

The results of statistical analysis showed that acacia leaves fermented using Aspergillus niger as much as $0-2 \%$ had a significant effect $(\mathrm{P}<0.05)$ on crude fat. The 
higher the dose of Aspergillus niger used in the fermentation of acacia leaves causes the crude fat content to increase as well

The increase in crude fat content during fermentation is due to the crude fat content originating from the mass of microbial cells that grow and multiply in the media during fermentation (Budiman, 2014). According to Soeparno (1998) in the research of Yuvita et. al., (2019) stated that there is bacterial activity that produces high enough fatty acids so that the fat content tends to increase. According to Ardhana (1982) in Suningsih et. al., (2019) stated that the organic matter that decreased during the fermentation process was starch and fat which were used to meet energy needs for yeast growth. While the results of this study showed crude fat content did not decrease but increased.

\section{Crude Fiber}

The results of the research on crude fiber content of acacia leaf fermentation using Aspergillus niger are listed in Table 3.

Table 3. Average Crude Fiber Content of Acacia Leaves Fermented with Aspergillis Niger (\%)

\begin{tabular}{cccc}
\hline \hline \multirow{2}{*}{ Repeat } & \multicolumn{3}{c}{ Treatment } \\
\cline { 2 - 4 } & P0 & P1 & P2 \\
\hline 1 & 69.2 & 72.1 & 66.3 \\
2 & 71.9 & 70.3 & 71.5 \\
3 & 70.4 & 69.7 & 67.5 \\
4 & 63.2 & 63.5 & 70.1 \\
5 & 66.1 & 66.5 & 64.7 \\
6 & 68.7 & 68.3 & 73.5 \\
\hline Average $^{\text {ns }}$ & 68.23 & 68.40 & 68.90 \\
\hline
\end{tabular}

Description ns : Non significant ( $\mathrm{P}>0.05$ )

Based on table 3 the crude fiber content in acacia leaf fermentation using Aspergillus niger showed the average values for $\mathrm{P} 0, \mathrm{P} 1$, and $\mathrm{P} 2$ treatments were $68.23 \%, 68.40 \%$, and $68.90 \%$.

The results of statistical analysis showed that fermented acacia leaves using Aspergillus niger had no significant effect $(\mathrm{P}>0.05)$ on crude fiber content. The addition of Aspergillus niger to fermented acacia leaves did not affect the crude fiber content of the acacia leaves. This shows that the fermentation of acacia leaves using Aspergillus niger as much as $0-2 \%$ which is fermented for 1 week has not been able to reduce crude fiber content.

Theoretically, crude fiber content will decrease due to the degradation of cellulose by Aspergillus niger, however crude fiber content can increase as a result of fiber content in mycelium and mold spores which are analyzed as crude fiber, mycelium and spores produced by Aspergillus niger, with increasing number of The inoculum will increase mycelium production which has an impact on increasing the value of crude 
fiber (Ahmat et. al., 2019). Ganjar et al., (2006) added that one of the important components of the cell wall is chitin and chitosan. Both components were counted as crude fiber in proximate analysis. Thus, the increase in crude fiber content could be caused by the presence of spores and mold mecilium in the tested material. Soares (2017) stated that the cellulase enzyme produced from Aspergillus niger inoculum was able to break down complex bonds from fibers into simpler components.

\section{Conclusion}

The results of this study concluded that Acacia leaves (Acacia Mangium) fermented using Aspergillus niger as much as $0-2 \%$ for 1 week had a significant effect on fat content, but did not significantly affect soluble protein content and crude fiber content of acacia (Acacia Mangium) leaves.

\section{References}

Ardhana, M. 1982. The Microbal Ecology Of Tape Ketan Fermentation. Thesis. The University of New South Wales University: Sydney.

Budiman, R. M. 2014. Analisis Kandungan Bahan Ekstrat Tanpa Nitrogen (BETN) dan Lemak Kasar Pada Rumput Taiwan ( Pennisetum Purpereum) dan Kulit Buah Pisang Kepok yang Difermentasi Dengan Trichoderma sp. Jurusan Peternakan, Fakultas Pertanian, Peternakan dan Perikanan UMPR. Parepare.

Ganjar, Indrawati,dan Wellyzar S. 2006. Mikrobiologi Dasar dan Terapan. Jakarta: Yayasan Obor Indonesia.

Ahmat, H., Baban M, dan Inggit K.. 2019. Pengaruh Alkalinasi Air Kapur Dan Fermentasi Jerami Jagung Menggunakan Aspergillus niger Terhadap kandungan Bahan Kering, Bahan Organik, dan Serat Kasar. Universitas Islam Malang. Jurnal Rekastwa Peternakan Vol. 1 No.1

Indrayanti, N., dan Rahmawati. 2013. Peningkatan kualitas nutrisi limbah kulit buah kakao dan danau lamtoro melalui fermentasi sebagai basis protein pakan ikan nila. Jurnal Penelitian Pertanian Terapan. 13 (2) : 108-115.

Mulyono. A.M. 2011. Rancangan Percobaan. Kepel Press. Yogyakarta.

Nuryana, R. 2016. Pemanfaatan selulosa dari eceng gondok sebagai bahan baku pembuatan cmc ( carboxymethyl cellulose) dengan media reaksi campuran larutan metanol-propanol. Laporan Akhir. Politeknik Negeri Sriwijaya. Palembang.

Soares, D., Irfan H. D., dan Muhammad H.N. 2017. Pengaruh Jenis Inokulum Aspergilus niger dan Saccharomyces Cereviseae Dan Lama Fermentasi Terhadap Komposisi Nutrisi Ampas Putak (Corypha Gebanga). Fakultas Peternakan, Program Studi Magister Ilmu Ternak. Universitas Brawijaya. Jurnal Ilmu-Ilmu Peternakan 28 (1): 90-95.

Soeparno. 1998. Ilmu dan Teknologi Daging. Edisi ke-3. Gajah Mada University Press. Yogyakarta. 
Suningsih, N., W. Ibrahim O., Liandris, R. Yulianti. 2019. Kualitas fisik dan nutrisi jerami padi fernentasi pada berbagai penambahan starter. Universitas Musi Rawas. Indonesia.

Supriyatna, A. 2017. Peningkatan Nutrisi Jerami Padi Melalui Fermentasi Dengan Menggunakan Konsorsium Jamur Phanerochaetae Chrysosporium dan Aspergillus Niger. Jurnal. ISSN 1979-1981. 10(2) : 166-181. 